\title{
SOME CONSEQUENCES OF THE RELATION BETWEEN GLACIER VARIATIONS AND CLIMATIC FLUCTUATIONS IN BRITAIN
}

\author{
By GoRdon Manley \\ (Bedford College for Women, University of London)
}

(Abridgement of a paper read before the International Commission on Snow and Glaciers, Oslo, 1948)

LARGELY as a result of Scandinavian work it has become possible in recent years to correlate the behaviour of glaciers with the trend of monthly and annual means of temperature at Stockholm during the past 200 years. ${ }^{1,2}$ While some have questioned the validity of the eighteenth-century records 3 it is particularly interesting to note that other long series of monthly means, eliminating the possible effects of urban exposure, have now become available for north-west England and Holland. ${ }^{4}, 5$ The trend of the independent English curves during the past 200 years is so much in accord with that of Sweden as to give further confidence not only in the reality but also in the amount and time of development of the present secular change. As a matter of interest it may be added that reports of the behaviour of the semi-permanent Scottish snowbeds since the eighteenth century indicate that they too have responded in broad agreement with the variations of the Norwegian and Icelandic glaciers.

It is hoped to extend the English records at least back to $17 \mathrm{I}_{5} 5$ and thus to reinforce Labrijn's figures ( 1706 onward) and I am not without hope of devising further methods of estimating the extent and character of the temperature fluctuations for the later seventeenth century. If this can be done we shall have a view of the temperature trend in north-west Europe covering Thorarinsson's curve of glacier oscillation in Iceland ${ }^{6}$ and about half of Matthes's "Little Ice Age." From the nature of this curve it may be possible to estimate the character of the events initiating the "Little Ice Age" and to suggest reasons why it may have begun in north-west Europe two centuries before the great advance of the alpine glaciers.

In discussing glacier behaviour in relation to climatic fluctuations it is, however, necessary to take a very general view and to disregard on the one hand the sometimes contradictory behaviour of individual glaciers, or the results of individual exceptional seasons. Further, we are often using very imperfect observations. Clearly one must think in terms of whole countries and of groups of years-amounting to decades at least; and one must try to bear in mind climatic agencies which will take effect over groups of years of that order of length, and which will be capable of predominating over a century or more.

For north-west Europe one of the fundamental agencies of this kind must surely be sought in the extent off east Greenland not merely of the Arctic pack, but of the melt water from the sea ice.

Ahlmann has shown that a slight rise or fall in spring and autumn temperatures is extremely effective with regard to the behaviour of glaciers in Norway; although July temperatures may remain unaffected, variations in May and October imply considerable changes in the length of the ablation season. In the diagram (Fig. I, p. 353) I have therefore put together the curves showing ten-year running means of temperature of the three months' period March-May, based on the English and Dutch records. The rises and falls agree remarkably well with the general features of Thorarinsson's curve of glacier behaviour for Iceland. ${ }^{6}$ But we may also note that the English instrumental record, allied with that from Holland, for the period immediately preceding one of the dates of maximum post-glacial advance of about $1745^{-5^{\circ}}{ }^{7}$ suggests that the occurrence of a small group of six or seven cold years, in which cold spring and autumn months were especially notable, is sufficient to lead to sudden and marked glacier advance. 


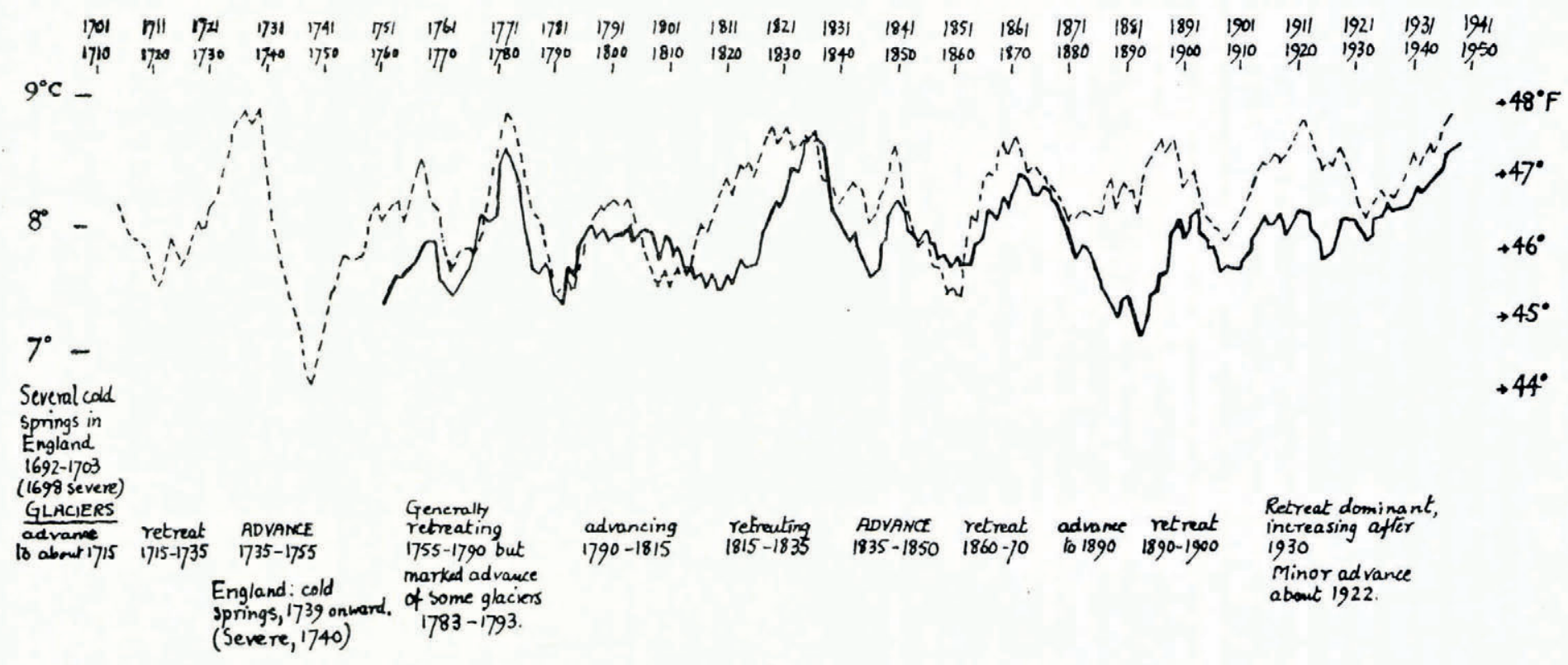

Fig. I. Ten-year running means of spring temperatures (March to May) in north England (contimuous line) and Holland (dashed line); below, the behaviour of Iceland glaciers

By courtesy of the Editor of the Quarterly Journal Royal Meteorological Society 
We must recall that in temperate insular and maritime climates in such months as May and October the temperature of the sea surface is more significant than that of the land. From this it can reasonably be suggested that one of the most important factors with regard to the temperature variations in England, and to glacier behaviour in Norway and Iceland, is the location of the border of the melt water from the Arctic ice. In these regions adjacent to the open north Atlantic maritime-polar air masses are dominant. Curves derived from ten-year running means should largely eliminate the effects of particular extreme months, and the multiple of such a curve, that is the range of variation of successive ten-year means, should therefore largely derive from variations in the average temperature of maritime-polar air. This average temperature in turn may be presumed to reflect the extent of the spread of colder water off Greenland and Iceland. A careful analysis of the small variations in mean temperature at stations ranging from Stykkisholm and Lofoten to Plymouth, that is in the region where maritime-polar air from the North Atlantic predominates, might make it possible to estimate the extent of the movement of this "Arctic convergence" during the past two centuries ( $c f$. Ericksson ${ }^{8}$ ).

Again, in the later eighteenth century the mean temperature for exceptionally warm winter months such as December 1806 or January 1759 and 1796 approximated to that of the warmest months of the same name in recent decades, e.g. December I934. Remembering the properties of air masses it would therefore appear that the sea temperature off the coast of south-west Europe must have been much the same as at present. Hence for the climate as a whole to allow of glacier advance it is difficult to resist the conclusion that maritime-polar air must have had a shorter travel from its region of origin. Apart from the possibility of increased wind speed the conclusion seems to be that there was a greater spread of Arctic water. Its limits would probably be approximately defined by the outer limit of occurrence of drift ice.

But here we open up several further questions. In particular, where does the increased supply of melt water come from? By what stages, and over what length of time does the relatively fresh surface layer in the Arctic basin increase in thickness? Thirdly, at what rate does mixing of the fresher surface layer with the underlying water of greater salinity proceed, for example in a direction south-eastward from the Greenland coast in the latitude of Iceland? The view of the physical oceanographers with regard to these problems would be welcome.

Climatic fluctuations in Britain however include not merely the minor episodes of the past two centuries. Since the Ice Age several larger scale variations are known and recent work in England has confirmed the occurrence in late glacial times in this country of a period similar to the "Allerød oscillation" already established in Denmark and Norway. The date of this period of climatic amelioration can be put at about 10,000 to 8200 B.c. The extent and character of this oscillation affecting north-west Europe might well be explained by adopting the view that a period of weak atmospheric circulation prevailed for many hundred years at a time when the sea off north-west Europe was still quite cold. The resultant mean temperatures near the coasts for July were of the order of $10^{\circ} \mathrm{C}$. $\left(50^{\circ} \mathrm{F}\right.$.) in north Ireland and south-west Norway, that is about $4^{\circ}-5^{\circ} \mathrm{C}$. lower than at present, based on botanical evidence.

This relatively warm "Allerød" phase is named after the location in Denmark in which the remains of birches were found sandwiched between layers in a peat bog devoid of such vegetation. This clearly indicated that an interval of improved climate occurred during the late Glacial, followed by a recession. Before this "Allerød" phase the climate, according to Mannerfelt, ${ }^{10}$ must have been characterized by vigorous atmospheric circulation, as, in his view, the manner in which the ice cap wasted in Scandinavia at that time is to be explained as the result of increased ablation by convection of maritime air from the open Atlantic. For long periods cloudy, windy and stormy conditions would prevail in Scandinavia. Following Angström, ${ }^{2}$ the present-day amelioration of climate during the last 50-100 years is similarly to be explained by "more vigorous circulation." After the "Allerød" period the subsequent deterioration can again be explained as 
the result of a lowering of the summer temperature with increased cloud and wind, at a time when the north Atlantic was still much cooler than now. The intermediate warmer and drier phase was probably characterized by more frequent and persistent anticyclones and less wind.

At a later stage during the post-glacial "climatic optimum" it has been shown by Iversen 11 that in Denmark (in the "Atlantic" phase) the summer temperatures were a little warmer than at present, while the winters were milder. This might well be explained by assuming the vigour of the atmospheric circulation to be much the same as now, but with considerably less "Arctic water" in the Norwegian Sea. During the Sub-Boreal we must again assume a predominance of anticyclones for long periods, i.e. "weak circulation." Later, following Brooks ${ }^{12}$ a rapid readvance of the Arctic water at a time when the circulation was still "vigorous" will explain the climatic deterioration of the Early Iron Age (about 500 B.c.). Minor re-advances of the Arctic water may also explain the other "recurrence-surfaces" for which the evidence has been summarized by von Post. $13 a, b$

These suggestions are made to illustrate the view that a careful study of all the evidence given by the instrumental record during the past 300 years (i.e. the "Little Ice Age") might go far towards elucidating the causes of the Pleistocene Ice Age in north-west Europe.

But the volume of the Arctic melt water may, in the past, have owed a great deal to the Greenland Ice Cap as well as to the sea ice. In my view we should also take into account the views of Wager that the Greenland Ice Cap was already in existence in the Miocene 14 : his concept seems to me to be extremely important in any discussion of Pleistocene glaciation. It may be bold; but I should like to suggest that geophysicists better qualified than I should study the rate at which the cooling of the seas would then proceed, in order to explain the lapse of time before the peripheral ice caps of Scandinavia and Laurentia became established. It would be interesting to have further knowledge of the time of uplift of the Scandinavian mountain system to a level at which glaciation would be initiated. For, as Dahl ${ }^{15}$ has shown, it is still necessary to have a reasonably open sea and relatively mild temperatures on the north-west coast of Norway at the height of the last phase of glaciation.

But it is similarly necessary to have an open sea off Ireland, yet with a surface temperature which could scarcely be more than $5^{\circ} \mathrm{C}$. This is evident, because at the height of the glaciation the firn line in north England even in midsummer can scarcely at best have exceeded $600 \mathrm{~m}$. above sea level. Further, the Atlantic off Scotland and north-west Ireland must have had a great deal of scattered drift ice. These facts lead us to the conclusion that whereas pack ice did not completely cover the Norwegian Sea the spread of cool surface water driven by the westerly winds may even have extended to the parallel of $50^{\circ} \mathrm{N}$. from its present position north and west of Iceland $(c f$. here the interesting maps in Flint 16 and the views of Simpson. ${ }^{17}$ One may regard this spread of the cooler surface waters, overlying the warmer salt water of the North Atlantic drift between the Labrador seas and the west of Ireland, as analagous to an "occlusion".

Following up Wager's view we may suppose a long period during which the Greenland Ice Cap existed adjacent to an open sea. Ultimately a border of extensive pack ice developed, to such an extent that we must assume that Greenland would be starved of precipitation, as the Antarctic now is. Presumably, therefore, isostatic recovery of Greenland would in due time set in. If we accept Umbgrove's ${ }^{18}$ views of the relationship of large-scale glaciation to the periods of orogenic uplift it remains for geophysicists to explore the interesting possibility of explaining multiple glaciation in terms of successive isostatic depression and recoveries, following a long period during which the seas were slowly cooled as a result of the mid-Tertiary elevation of Greenland.

In such an event, based on Wager's views and on such indications as we have from the Antarctic, we should be able to equate in broad terms the length of the glaciation following the Alpine orogeny with that suggested for the Upper Palaeozoic glaciation, namely twenty-five million years. ${ }^{18}$ 
No doubt this appears a tremendous leap from the contemplation of the instrumental observations of the eighteenth century kept by our ancestors in various parts of north-west Europe. But I believe it is for a geographer to endeavour, even at some risk, to provide material for discussion by those better qualified to make more detailed studies. Minor studies, centering round the reasons for the small groups of colder years within the record, may nevertheless open up the major problem of the ways in which the cooling of the seas was begun, both in the deep oceans and on the surface. Now that it has been shown by the Scandinavian glaciologists that we have so recently emerged from a period of maximum post-glacial advance we are in a position to link up and compare the results from a variety of sources in the realms of glaciology, oceanography and meteorology. It is not inappropriate that the countries round the North Sea which have done so much in these realms of observational science should now bring together their results; I hope that these suggestions may lead to further development.

\section{R E F E RE N C E S}

I. Ahlmann, Hans W:son. Glaciological research on the north Atlantic coasts. Royal Geographical Society Research Series, No. 1, 1948, 83 p.

2. Angström, Anders. The change of the temperature climate in present time. Geografiska Annaler, Arg. 21, Ht. 2, 1939, p. II9-31.

3. Egedal, J. Om variationer af middelværdien af lufttemperaturen over Nordvesteuropa. Geografisk Tidsskrift (Kjøbenhavn), Bd. 46 , I 943 , p. 58-71.

4. Manley, Gordon. Temperature trend in Lancashire, 1753-1945. Quarterly fournal Royal Meteorological Society, Vol. 72 , No. 311 , p. $1-31$.

5. Labrijn, A. The climate of the Netherlands during the last two and a half centuries. Mededeelingin en Verhandelingen, No. 49, Koninklijk Nederlandsch Meteorologisch Instituut (Gravenlinge), 1945.

6. Thorarinsson, Sigurdur. Oscillations of the Iceland glaciers in the last 250 years. Geografiska Annaler, Ảrg. 25 , Ht. I-2, I 943 , p. I-54.

7. Werenskiold, W. Glaciers in Jotunheim. Norsk Geografisk Tidsskrift, Bd. 7, Ht. 5-8, 1939, p. 382-9r.

8. Ericksson, B. E. Till kännedomen om den nutida klimatändringen inom områdena kring nordligaste Atlanten. Geografiska Annaler, Årg. 25, Ht. 3-4, 1944, p. 170-201.

9. Pennington, W. Studies of the post-glacial history of British vegetation. Philosophical Transactions Royal Society of London, Series B. Vol. 233 , No. 596, 1947, p. $137-75$.

10. Mannerfelt, Carl M:son. Nảgra glacialmorfologiska formelement. Geografiska Annaler, Ảrg. 17, Ht. 1-2, I945, p. $x-239$.

11. Iversen, J. Viscum, Hedera and Ilex as climatic indicators. Geologiska Föreningens i Stockholm Förhandlingar, Bd. 66, Ht. 3 , 1944, p. $463-83$.

12. Brooks, C. E. P. Climate through the ages. London: Ernest Benn., Revised edition 1949.

13. (a) Post, L. von. The prospect for pollen analysis in the study of the earth's climatic history. The New Phytologist (Cambridge), Vol. 45, No. 2, 1946, p. 193-217.

(b) Conway, V. M. Von Post's work on climatic rhythms. Ibid., Vol. 47, No. 2, 1948, p. $220-37$.

14. Wager, L. R. The form and age of the Greenland ice cap. Geological Magazine, Vol. 70, No. 4, 1933, p. $145-56$.

15. Dahl, E. On the origin of the strandflat. Norsk Geografisk Tidsskrift, Bd. I I, Ht. 3, I946, p. I $59-7 \mathrm{I}$.

16. Flint, R. F. Glacial geology and the Pleistocene epoch. New York: John Wiley \& Sons; London: Chapman \& Hall, Ltd., 1947.

17. Simpson, G. C. World climate during the Quaternary period. Quarterly fournal Royal Meteorological Society, Vol. 60 , No. 257 , p. $425-78$.

18. Umbgrove, J. H. F. The Pulse of the Earth. Second edition. The Hague: Martinus Nijhoff, 1947, $35^{8}$ p.

\section{GLACIER FLUCTUATION IN THE ALPS I947-48}

IN the summer of 1948 heavy precipitation caused an increase of the snow reservoirs in the upper reaches of the glaciers, but rain at lower levels caused the general process of ablation to continue although at somewhat lessened speed. Some glaciers even re-advanced. Dr. P-L. Mercanton in his report * shows that during 1948 I3 per cent of the glaciers had advanced, ro per cent were stationary and 77 per cent were in recession. In 1947 the respective percentage figures were 0,2 and $98 . \dagger$

* Die Alpen, Vol. 25, No. 7, 1949, p. 267-73.

† From details received from the Comitato Glaciologico Italiano (Revista del Club Alpino Italiano, N. 7-8, 1949, p. $113^{-18)}$ in 19474.2 per cent of the Italian glaciers under observation had advanced, $11 \cdot 1$ per cent were stationary or indeterminate and 84.7 per cent were in recession. 